themanummers over het lot van weduwen (2/ 98), zigeuners ( $4 / 98)$ en 'Tribes' ( $4 / 99$ ): boeiend, goed geschreven en gedocumenteerd, maar ver verwijderd van het oorspronkelijke aandachtsgebied van censuur.

Een onderdeel van het tijdschrift dat in vijfentwintig jaar niet is veranderd en wel gericht is op censuur is de rubriek 'Index Index': een lijst van censuurfeiten van over de hele wereld, gerangschikt per land in alfabetische volgorde. De lijst wordt samengesteld met behulp van gegevens die zijn verzameld door talrijke organisaties en contactpersonen over de hele wereld en biedt een grote rijkdom aan informatie. Bovendien documenteert de lijst ook politieke veranderingen omdat je aan de hoeveelheid berichten per land kunt afleiden hoe het daar staat met de mensenrechten. Tot 1994 werden aan Zuid-Afrika bijvoorbeeld minstens vier kolommen besteed en na de verkiezingen verschijnen nog maar enkele berichten per keer.

\title{
ELS STRONKS
}

\section{$\nabla$}

Justus van Effen, De Hollandsche Spectator. Aflevering $31 \mathrm{t} / \mathrm{m}$ 6o en $106 \mathrm{t} / \mathrm{m} 150$.

Ed. E. Groenenboom-Draai en S. Gabriëls, Duivelshoekreeks 8 en 9, Leiden 1998.

.................

Er is wellicht geen betere manier om het literaire klimaat van het achttiende-eeuwse Nederland te leren kennen dan door het lezen van De Hollandsche Spectator van Justus van Effen. Van Effens schrijfsels hebben de literaire vorm die kenmerkend is voor die dagen: de vorm van een spectatoriaal tijdschrift, met een hoofdredacteur die als 'spectator' de zeden en gewoonten van zijn landgenoten bekijkt en er iets aan probeert te veranderen in het licht van de belangrijkste idealen van de Verlichting - redelijkheid, verdraagzaamheid en sociabiliteit. In het tijdschrift staan vertogen, brieven, fabels, persiflages, gedichten, novellen en reisverhalen, gevuld met observaties en moralistische lessen en adviezen.
Het boek Embarrassment of Tyrannies laat de hierboven beschreven ontwikkelingen zien aan de hand van $\sigma_{2}$ bijdragen (artikelen, gedichten, verhalen, interviews) die gepubliceerd zijn in Index on Censorship tussen het voorjaarvan 1972 en 1997. Bij de selectie van de auteurs is vooral gekozen voor bekende schrijvers zoals Solsjenitsyn, Gordimer, Rushdie, Chomsky en Soyinka. Het boek geeft een boeiend overzicht van vrijheid van meningsuiting wereldwijd en biedt bovendien een perspectief op de politieke geschiedenis van de afgelopen vijfentwintig jaar. Eerst ligt de nadruk vooral op Oost-Europa en de schrijvers daar, later richt de aandacht zich op andere landen en op nieuwe media. Wie de ontwikkeling van het tijdschrift en de politieke veranderingen van de laatste decennia echt wil ervaren doet er goed aan de oude jaargangen een keer op te zoeken in de bibliotheek en rustig door te bladeren.

Het spectatoriale tijdschrift is te zien als barometer van de literaire smaak. Door de vorm, maar ook door zijn inhoud. Van Effen bekijkt als spectator alle aspecten van de toenmalige samenleving, van kleedgedrag tot samenlevingsvormen en van sociale hiërarchie tot het probleem van laster en achterklap. Onder al die onderwerpen bevinden zich ook zaken die met het literaire bedrijf te maken hebben: welke idealen horen schrijvers te hebben, welk genre zou de boventoon moeten voeren, welke 'oude schrijvers' dient men in ere te houden, welk leesgedrag is gepast, hoe dient men tegen het verschijnsel 'broodschrijver' aan te kijken, in welke organisaties dienen schrijvers zich te groeperen, en welke eisen kunnen aan verantwoorde poëzie gesteld worden een kleine greep uit Van Effens opmerkingen in De Hollandsche Spectator over literatuur en alles wat daarmee samenhangt.

Wie die opmerkingen meer in detail gaat bekijken, komt soms tot verrassende ontdek- 
kingen. Van Effen blijkt bijvoorbeeld een groot bewonderaar van Jacob Cats (zie aflevering 37). Dat lijkt wat eigenaardig; Van Effen predikt immers op velerlei gebied vernieuwing. De idealen van de Verlichting die hij in het gedrag van zijn landgenoten weerspiegeld wilde zien, betekenen een breuk met het voorafgaande. En Cats staat in zekere zin - nu juist model voor dat voorafgaande, door de plaats die de klassieken in zijn werk innemen, door de eentonigheid van zijn alexandrijnse dreunen, en door zijn behoudende standpunten in zaken van moraal en ethiek. Dat alles stoort Van Effen niet, omdat hij een andere kant van Cats' dichterschap ziet: die van het 'Poetisch vermogen' van de 'uitgestrekte en levendige verbeeldingskracht'. Cats' roem is ten tijde dat Van Effen schrijft, 1732, reeds vervlogen. De beroemde volksdichter van weleer is 'in den afgrond van de uiterste veragting' neergestort. Ten onrechte dus, want men ziet dan toch de belangrijkste verdienste van deze dichter over het hoofd: het talent om 'denkbeelden' op te wekken en 'konstig [te] schakeren'. Het talent dus van de 'ware vinding'.

In een andere aflevering (no. 106) gaat Van Effen in op het verschijnsel 'vaerzemakers', of liever gezegd, op het 'uitschot der vaerzemakers'. Dichters die zichzelf dichters noemen, maar die in poëtische vinding ver achterblijven bij het ideaal.
Vaakzijn het schrijvers 'om den broode', voor wie de inhoud van wat te schrijven waarheid of leugen - niet uitmaakt, en die zich om stijl al helemaal niet bekommeren. Tussen de regels door kan men het ideaalbeeld Van Effen duidelijk uit deze kritiek zien opdoemen. Een goede inborst van de dichter is voor hem van minstens even groot belang als het vermogen groots en associatief te denken en te 'verbeelden'.

Al met al leveren de afleveringen van De Hollandsche Spectator voor veel lezers en onderzoekers van nu interessant materiaal, al was het maar omdat de achttiende-eeuwse tijdgeest er zich zo duidelijk uit af laat lezen. Met twee nieuwe delen in de serie heeft uitgeverij Astraea nieuw leven geblazen in een initiatief dat stamt uit 1984 , toen uitgeverij Sub Rosa met editeur P.J. Buijnsters de eerste afleveringen van De Hollandsche Spectator als fotomechanische herdruk op de markt bracht. De nieuwe delen bieden een goede inleiding, en een goed verantwoorde editie, die niet erg uitgebreid maarwel bruikbaar ontsloten is. Veel geannoteerd is er niet, maar er zijn wel goede indexen en samenvattingen van de afleveringen opgenomen, zodat onderzoekers hun weg in dit materiaal toch gemakkelijk kunnen vinden. Voor de 'gewone' lezer biedt De Hollandsche Spectator vooral veel leesgenot, door Van Effens uitgesproken voor-en afkeuren en zijn meeslepend temperament. 